\title{
THE RECENT PROPERTY LEGISLATION IN ENGLAND
}

It is difficult for English lawyers to grasp the effect of the recent statutes which came into operation on January ist last and which have gone far towards revolutionizing the old law of real property. Even mature practitioners are more or less at sea for the moment and the last six months have witnessed a curious spectacle of lecture classes presided over by enterprising barristers for the benefit of the other branch of the profession. Solicitors grumble that they are at school again. Innumerable questions are addressed each week to the technical journals by perplexed practitioners, and even the Lord Chancellor himself has been heckled on the woolsack by noble but querulous Lords. If this is the state of affairs in England, the present writer may surely be excused a little self-pity in the task which must be attempted in the following pages, the task, that is to say, of presenting an intelligible epitome of the new Acts for the benefit of American lawyers who are necessarily, and happily, unfamiliar with some of the worst technicalities of the old system of land law in England. An attempt, however, will be made to indicate the broad outline of the legislation.

First, we must say a word about the history of the legislation, for though our chief concern is with the six Acts passed in I925, it must not be thought that all the changes which they introduce are new ideas that have occurred to conveyancers since the War. To discover the origin of some of the new enactments we have to go back to 1897 . In that year Lord Davey introduced a Conveyancing Bill into the House of Lords which contained the germ of the present legislation in that it adumbrated the idea of having only two legal estates, namely, the fee simple and the term of years. It also provided that a transfer of land should carry the whole fee simple or the whole term, subject to what were called paramount rights, such as easements, but free from fiduciary rights, such as the rights of beneficiaries under a trust. Other points of interest in the Bill were that the owner of a legal estate was called an "estate owner," the fee simple of settled land was 
made to vest in the tenant for life, and any tenant in common could procure an order vesting the land in trustees for sale. We shall see all these points cropping up in the I925 Acts. The Bill, however, after having been read a second time, was dropped. Then, in I909, a Royal Commission was set up with the object of ascertaining whether it was advisable to extend the system of compulsory registration. But the conclusion reached by the Commission in I9I I was that instead of extending registration, the right plan was to simplify the existing law of real property, and among the suggestions put forward were the compulsory enfranchisement of copyholds and the abolition of the rule requiring words of limitation.

The next stage was reached in 1913 when Lord Haldane brought forward his Conveyancing Bill and Real Property Bill. The former, inter alia, divided interests in land into "proprietary interests" (legal and equitable fees simple and terms of years absolute); "paramount interests" (easements, etc.); and "subordinate interests" (rights of beneficiaries) - a terminology which was connected with an extension of what is called the "curtain principle," that is, a conveyance by a "proprietor" was to be subject to paramount interests but was to over-reach subordinate interests unless protected by cautions. The Real Property Bill enacted a number of changes which appeared in the 1925 Acts, including the abolition of copylolds and perpetually renewable leases and words of limitation. The Bills, however, disappeared in the fog of war.

The last stage begins with the end of the War. In rgrg there was issued the Fourth Report of the Acquisition and Valuation of Land Committee, the terms of whose reference were "To consider the present position of land transfer, and to advise what action should be taken to facilitate and cheapen the transfer of land." Now the suggestion which had the greatest influence upon the deliberations of the Committee and which must be grasped by anyone who desires to appreciate the main drift of the ensuing legislation, was that put forward by Sir Arthur Underhill in a pamphlet entitled, "The Line of Least Resistance." The object desired by all was to simplify conveyancing and the only problem 
was to discover the easiest method of attainment. Sir Arthur Underhill pointed out that the complications which attended the transfer of land were principally due to the complexities of real property law. That law, as the result of old feudal doctrines, imposed upon us three distinct systems of land law. There was the law of freeholds, which was overlaid with much difficult learning about estates, seisin, contingent remainders, executory interests under the Statute of Uses, and so on; there was the law relating to leaseholds which was far less complicated because, being unaffected by the doctrine of estates, it only admitted of absolute ownership in much the same way as stocks and shares did; and lastly, there was the law of copyholds which, in several important respects, was different both from the law of freeholds and the law of leaseholds. Therefore, advocated Sir Arthur Underhill, all that was necessary in order to put land transfer upon a more sensible footing was, first, to turn copyholds into freeholds, and then to enact that the law which applied to leaseholds should also apply to freeholds. In other words, first get rid of the copyholds and then assimilate realty and personalty. He advised that after the abolition of copyholds the main design could be effected by passing a short Act to provide that a fee simple estate should for all purposes of disposition, settlement on persons in succession, transmission, devolution, distribution and administration of assets on death, have all the incidents of a chattel real estate, save only that it should continue in perpetuity. This general principle was adopted by the Committee and Sir Benjamin Cherry was instructed to embody it in a draft Bill. The ultimate result, however, of the draftsman's labors was not a Short Act as contemplated by $\mathrm{Sir}$ Arthur Underhill, but the Law of Property Act, 1922 which, besides incorporating the assimilating principle, adopted many of the revolutionary ideas contained in Lord Haldane's Bills and effected many incidental amendments of the existing Conveyancing, Settled Land, Trustee and Land Transfer Acts.

This r922 Act ran to over three hundred pages, but, in the course of its passage through Parliament, an assurance was given that it should later be split up into a number of separate Acts 
which should not only put the changes in the appropriate enactment but should also consolidate the existing statute law of real property. When this consolidating process was begun it was found necessary to appoint another committee to consider what further amendments of the old law were necessary in order to bring the new ideas of the 1922 Act into line with the existing statutes. This proved a troublesome matter but, to cut a long story short, the course of ensuing legislation was as follows. In the first place the coming into operation of the Law of Property Act, 1922, was postponed to January I, 1926. The Law of Property (Amendment) Act, I924, was then passed which did two thingsit repealed all but the transitional provisions of the $1922 \mathrm{Act}$, and it set out the new provisions which were to take the place of the repealed portions. Then, in 1925, there were passed the Law of Property Act, the Settled Land Act, the Land Charges Act, -the Administration of Estates Act, the Land Registration Act, and the Trustee Act. These 1925 Acts brought up to date all the old Acts bearing similar titles and incorporated in them the alterations introduced by the 1922 Act as amended by the 1924 Act. To discover, then, the existing statute law of real property, we go to the unrepealed parts of the Law of Property Act, I922 (i. e., Parts $v$ and vi and Schedules 12-15, dealing with the abolition of copyholds and perpetually renewable leases, and the extinguishment of manorial incidents) and to the six I925 Acts. All of these came into operation on the first of January last.

Ve have seen what the general idea of all this legislation is. It is to turn copyholds into freeholds and then to assimilate freeholds and leaseholds. Let us see quite briefly how these two objects have been attained.

As regards the first point, it may be said with some degree of assurance that all tenures have now been reduced to one common form, namely, socage. Copyhold tenure became automatically converted into free and common socage on January I, 1926. All those variations on the general law such as gavelkind and Borough English, have also been abolished. It was intended to abolish Frankalmoin but, owing to the peculiar manner in which the matter was dealt with, it is doubtful whether the abolition is effective. 
The honorary services, where they exist, incident to land held by grand and petty sergeantry are retained. Escheat is replaced by the right of the Crown to take land as bona z'acantia. In other words, though the doctrine that every acre of land is not owned but is held of King still remains true, it has no practical effect, for all land is held by socage tenure and socage tenure is only another expression for absolute ownership. The direct results of feudalism have at last disappeared. The subject of copyholds does not, however, end with the conversion into freehold, for copyhold tenure involved certain manorial incidents which were of considerable pecuniary value to the lord of a manor. It is therefore provided that within the next ten years arrangements must be made between the lord and tenant for the payment to the former of compensation for the loss of such incidents as bear a money value. When such compensation is fixed, the manorial incidents are extinguished.

IVe can now turn to the assimilating provisions. 'It should be remenbered here that the 1925 Acts only conplete a process which has been continuing for centuries, for the tendency has always been to extend the law of leaseholds to real property, a fact which can be appreciated if one considers such matters as the remedies for dispossession, the power of testamentary disposition, the availability of property for creditors and its devolution to personal representatives. But the process has now been carried as far as is humanly possible, and the differences which still existed in 1925 between the law applicable to freeholds and that applicable to leaseholds have been swept away. Perhaps the most important point upon which assimilation has been attained is in connection with the quantum and nature of the interest which can be created in the two forms of property. As regards real property in the strict sense the rule prior to 1926 , both at common law and in equity, was that land was not the subject of ownership but only of tenure. A person who, in the popular sense, owned land did not really own it but was the holder of an estate therein. But the number of estates which might subsist, either at law or in equity, was fairly considerable, and moreover it was possible to take the legal fee simple and to carve it into a 
number of partial and successive legal estates in the form either of remainders or executory interests. The position with regard to personalty was different. At common law pure personalty or existing leaseholds were the subjects only of absolute ownership and they could not be carved into estates. There could be no limitation of partial and successive interests either by way of remainder or a grant to uses. Equity, on the other hand, did allow personalty to be split up to a limited extent into a series of successive interests if the legal ownership was vested in trustees and a settlement made of the equitable interest, but yet it was quite impossible even in equity to limit an estate tail. in personalty. Thus in personalty it was impossible to have legal life estates, it was possible to have equitable life estates; it was impossible to have legal or equitable estates tail. All this is now changed. It is enacted that the only legal estates which can be created in land are the fee simple absolute in possession and the term of years absolute, although the term "legal interests" has been adopted to cover such interests as easements and rent-charges provided that they are held in perpetuity or for a term of years absolute. Thus the old life estates, estates tail, whether in possession or remainder, are no longer legal estates but, to adopt the new terminology, equitable interests. Again, it is expressly enacted that entailed interests can be created either in chattels real or chattels personal. The results under this head, then, are that the same partial estates can be created in personalty as could formerly have been created in realty, and that, whether created in realty or personalty, they must always be equitable in nature.

We must pass hurriedly over the other points of assimilation, and perhaps it will help if we present them in tabular form.

\section{(I) Descent on Intestacy}

Before 1926 there was one set of intestate rules for the fee simple and another for chattels real and personal. Both these have been abolished except with regard to the descent of entailed interests, and a new set invented and made applicable to realty and personalty. Both forms of property will now be sold and the proceeds distributed in accordance with a uniform set of rules. 


\section{(2) Order in Which Assets Are Applied in Payment OF DEBTS}

In the case of a person who died before 1926, the order in which his property was taken in order to satisfy the claims of his creditors was based upon the distinction between realty and personalty, the general principle being that the general personal estate was the primary fund. A new order has now been devised which puts realty and personalty on the same footing.'

\section{(3) Words of Limitation}

It was necessary under the old law to use technical words of limitation in the conveyance of a fee simple estate, but a grant of a leasehold carried the whole interest of the grantor even though no special words were used. It is now provided that a conveyance of freehold lands without words of limitation shall pass the fee simple or other whole estate which the grantor has power to convey unless a contrary intention appears in the conveyance.

\section{(4) Method of Creating Mortgages}

Mortgages of the fee simple must now be created by means of a lease for a term of years just as, in the past, mortgage of a leasehold interest was made, in most cases, by means of sublease.

\section{(5) The Rule in Dearle v. Hall}

The rule, prior to 1926 , was that if there were several mortgages or assignments of an equitable interest in land, the priorities as between the various assignees depended on the order of time in which they had acquired their rights; but that if the subject-matter was an equitable interest in pure personalty, then the priorities were settled by the order in which the assignees had given notice of the transaction to the trustees or other legal owner of the fund. This last rule, known as the rule in Dearle v. Hall, has now been extended to dealings with equitable interests in freeholds and leaseholds.

So much, then, for the assimilating provisions. But there is unfortunately more to be said before we can gain even a faint 
idea of the extent of the changes wrought. The changes which we have already noticed have not been made in order to satisfy the dictates of logic and orderliness but simply and solely to the end that the transfer of land may be cheapened and facilitated. It is in this very matter of transfer that the difference between land and pure personalty is perhaps most marked. If we contrast the procedure which takes place upon the sale of land with that which obtains on the sale of stock, we cannot but agree with the layman that the result is very much in favor of the latter. The layman complains that it is more troublesome to convey a plot of land worth $£_{500}$ than it is to transfer a hundred thousand pounds worth of shares. This is true in general and it is conceived that it must always remain true for the simple reason that the physical differences between the two forms of property produce an entirely different situation in law. From a conveyancing point of view land is distinct from goods and stock in two main particulars. In the first place it is seldom safe for a purchaser to conclude that the person who is ready to sell him the land is the fee simple owner, for it may very well be that, despite his position as apparent owner, the vendor may possess a mere life interest or term of years. Secondly, land, owing to the permanent qualities which it possesses, is more often that not subject to what, for want of a better term, we may call third party rights, - rights, that is, which may continue to be enforceable against a purchaser. Easements, restrictive covenants, rent-charges, equitable charges, rights of beneficiaries under a settlement-all these are examples of the danger which besets the path of the intending purchaser. For these reasons, then, it is necessary that the purchaser should investigate with some care the title of the vendor, and it is investigation of title, together with the doctrine of constructive notice, which increases the cost and delay of land transfer and arouses the fury of laymen. The matter is not nearly as complicated in the matter of the transfer of stock. Here the owner whose name is entered on the Register is the legal owner; the stock may be held by the registered owner as trustee for others but no such equities. are allowed to be entered on the register; a purchaser will be safe in dealing with the registered owner and he will take a title free 
from the equitable interests of third parties. A curtain, as it were, consisting of the Register, is raised between the purchaser and the beneficiaries. Their concern is not with him but with the person who has received the money.

Why should not the conveyance of land be made as simple as the transfer of stock? We take the answer to be that land is peculiarly' subject to third party rights some of which cannot be transferred to the purchase money but must remain enforceable against the land. A system of compuisory registration of title might, of course, be introduced, but the English scem determined to retain their practice of private conveyancing, and while this is the feeling of the country all that the legislature can do is to improve matters by extending to transfers of land the principles which are applicable to the transfers of stock in all cases where the land is subject to third party rights. This the 1925 Acts have attempted to do. No vital alteration in procedure has been introduced where the land to be conveyed is vested for an unincumbered fee simple in an absolute beneficial owner. But wherever the land which is the subject of the transfer is subject to third party equitable rights in such a way that under the old practice a purchaser would be obliged to enter into a lengthy investigation of title (as in the case of strict settlements), or wherever the purchaser would, under the doctrine of notice, have taken the legal state subject to some outstanding equity, new provisions have been introduced which enable a vendor to pass a title to the legal estate free from such third party rights as can be made enforceable against the purchase money instead of against the land, and free from any obligation on the part of the purchaser to investigate any third party rights. These rights are over-reached by the conveyance and become enforceable only against the trustees into whose hands the purchase money must be paid. Thus we approach more nearly to the practice which obtains on the transfer of stock. There are four main principles which may be singled out as responsible for this result.

First, as we have seen, the number of legal estates is reduced to two. One effect of this is that although it is still law that a purchaser is bound by legal estates affecting the title con- 
vcyed to him whether he has notice or not, yet there are fewer estates which can exist as legal estates and therefore fewer to which a purchaser must be liable.

Secondly, provision is macle that, no matter what limitations may have been raised of the land, the lcgal fee simple shall atways be vested in somebody capable of transferring the same. In other words the basis of conveyancing has been shifted from powers to estates. Under the old law, for example, a tenant for life under a strict settlement was empowered to convey the fee simple to a purchaser but he did this by virtue of the statutory power conferred upon him by the Settled Land Acts. Now he does it, not by virtue of a power, but because the legal fee simple is actually vested in him.

Thirdly, the principle of registration has been extended. Not registration of title, be it noted, but of third party rights. The Acts allow practically every equitable interest that can exist to be registered as a land charge, and enact that registration shall constitute notice, but that absence of registration shall render the interest unenforceable even against a purchaser who had actual notice of its existence.

Fourthly, the curtain principle has been extended. Under the old law the rule was, that wherever land had been conveyed to trustees in trust for sale, the trustees could pass the legal estate to a purchaser free from the equitable rights of the beneficiaries in the proceeds of the sale. This over-reaching principle has been extended in two directions. There are certain cases $(c . g$. , where land has been granted to tenants in common) in which a trust for sale automatically arises, so as to admit of the legal estate being conveyed free from the equitable rights of the tenants in common. Again, an owner of land whose estate is not subject to a settlement or trust for sale, but is subject to some equitable right, such as a rent-charge for life, vested in a third party, is allowed within certain limits to create a trust for sale ad hoc and thus to pass the fee simple free from the equitable right.

There are a few further points, designed to carry out the above principle, which may be briefly noted. 


\section{(I) Mortgages}

One principle of the new legislation is that the legal fee simple should always be vested in the real owner. In the case of mortgages of the fee simple, the result of the method of creation: adopted under the old law and of the maxim, "once a mortgage always a mortgage," was that though the mortgagor was the real owner, the legal estate was vested in the mortgagee. It is now impossible to make a mortgage by a conveyance of the fee simple. Two methods alone of creating legal mortgages are allowed. The borrower must either demise the land for a long term of years or he must grant a charge by way of legal mortgage, the result in this last case being to give the mortgagee the same rights as if he had taken a long term. Thus the mortgagor retains the legal fee simple, the mortgagee takes a legal term of years absolute, while subsequent mortgagees also take legal estates, $i$. c., each takes a term of years absolute one day longer than the term held by the immediately preceding mortgagee. Although he only possesses a term, a mortgagee when exercising his power of sale is enabled to pass a legal fee simple. Any person who possesses a legal or equitable mortgage affecting a legal estate may register the mortgage as a land charge unless he holds the title deeds, and the priorities of such mortgagees depend upon the order of registration.

\section{(2) Strict Setrlements}

In order to simplify the task of investigating title, a new method has been instituted for the creation of strict settlements. All such settlements must now be created by two distinct deeds. First, there must be a "vesting deed" which vests the legal fee simple in the tenant for life, describes the settled land, names the trustees and the persons having power to appoint new trustees and sets out any powers which may be exercised by the tenant for life in addition to those conferred by the Settled Land Act. Secondly, there is the "trust instrument" which declares the trusts affecting the land, i. e., the life interest of the first tenant, the widow's rent-charge, the portions and the entailed interests. Thus the tenant for life appears in two different guises. For con- 
veyancing purposes he is the owner of the legal fee simple, while for the purposes of beneficial enjoyment he is a mere life tenant. When he makes a conveyance, in exercise of his power of sale, he passes the fee simple because he has it, and he passes it free from the rights of himself and the other equitable beneficiaries under the settlement. The trust instrument is no longer abstracted, the purchaser's concern being with the vesting deed alone. If that deed contains the required particulars, the purchaser is bound to assume that the person in whom the legal fee simple is said to be vested is tenant for life and has the powers of tenant for life; that the persons named as trustees are actually the trustees; and that the other statements in the deed were correct at the date thereof. When a tenant for life dies, the legal fee simple vests in the trustees as "special" personal representatives and is transferred by them to the next tenant for life.

\section{(3) Undivided Shares}

A tenancy in common has always been a hindrance to conveyancing because of a purchaser's obligation to trace the title of each tenant. This obligation is now removed for it is provided that never again can there be a tenancy in common of a legal estate. If land is limited to $A, B$ and $C$ as tenants in common, the legal estate vests in $A, B$ and $C$ as joint icnuats in trust to sell and to give effect to the equitable rights of $\mathrm{A}, \mathrm{B}$ and $\mathrm{C}$ as tenants in common. Thus a tenancy in common may still exist with regard to the equitable interest but when it does it invariably produces a joint legal tenancy. Joint tenants have one title and therefore a tenancy in common is no longer an impediment to the transfer of land.

\section{(4) Future Interests}

That most difficult part of the old property law which dealt with the limitation of future interests has been simplified beyond all recognition. This is due to the repeal of the Statute of Uses and to the fact that under the new classification of estates and interests, all future interests must be equitable in nature. The result is that we are thrown back to the period before 1535 , when 
the Chancellor allowed a person who put his lands in use complete liberty with regard to future limitations of the equitable interest. At the present day no future legal estate can be created by way either of remainder or of a grant to uses, but a settlor or devisor, provided that he creates a trust, can make what future limitations he chooses within the limits prescribed by the Rule against Perpetuities. The old common law rules for remainders have gone, as also has the necessity to act under the Statute of Uses in certain cases and there is no longer any difference between limitations in deeds and limitations in wills.

We must now bring to a close what is admittedly an inadequate endeavour to present an intelligible outline of the new Acts. The subject is too vast for elucidation in one article and there are several points of interest-such as the new power to devise entailed interests and the abolition of the Rule in Shelley's Casewhich have not been described, but if enough has been said to stimulate the interest of American lawyers in a revolutionary piece of legislation, the present writer will consider himself repaid.

Oxford, England.

G. C. Cheshire. 